\title{
Time Dependent Live-bed Scour Around Circular Piers under Flood Waves
}

\author{
Firat Gumgum ${ }^{1 *}$, Mehmet Sukru Guney ${ }^{2}$ \\ ${ }^{1}$ Civil Engineering Department, Dicle University, 21280 Diyarbakir, Turkey \\ 2 Department of Civil Engineering, Izmir University of Economics, 35330 Balçova, Izmir, Turkey \\ * Corresponding author, e-mail: firat.gumgum@dicle.edu.tr
}

Received: 10 July 2019, Accepted: 18 November 2019, Published online: 23 December 2019

\begin{abstract}
The aim of this study is to investigate live-bed scour under unsteady flow. During the experiments, 16 different triangular hydrographs were generated. Circular piers with three different diameters were tested under these hydrographs. Uniform bed material of $1.63 \mathrm{~mm}$ diameter was used during the experiments. The effects of the peak flow rate, the duration of hydrographs and the pier diameter on scour were interpreted. It was observed that the dominant element of the scour was the flow rate during the rising limb and the sediment transport rate during the falling limb. Maximum scour depths took place near the peak flow and lower final scour depths occurred at the end of the hydrograph. Two empirical equations were derived to predict time dependent scour depth and maximum scour depth. Statistically significant determination coefficient values and scatter indices were obtained.
\end{abstract}

\section{Keywords}

live-bed scour, bridge pier, flood waves, unsteady flow

\section{Introduction}

Local scour around the bridge piers was registered as the most important reason for the bridge failures. Between 1989 and 2000 in the United States, $48 \%$ of more than 500 bridge failures were caused by flood and scour, and $62 \%$ of these failures were directly related with floods [1].

Although there are many studies about local scour around the bridge piers, most of them were performed under clear-water conditions. In the studies carried out under livebed conditions, the experiments were generally realized under steady flow conditions. There exist also some experiments with stepwise hydrographs. Kothyari et al. [2] stated that the peak flow rate may not be effective long enough to develop its full potential, so the scour depth estimated by relations of steady flow conditions could be overestimated. This overestimation may increase the cost of the structure and safety precautions. In this study, live-bed scour experiments were conducted under various hydrographs in order to discuss the effect of unsteady flow on live-bed scour.

Scour resulting from an object that directly obstructs the flow is referred to as local scour. This object can be a bridge pier, an abutment or an open-channel junction. If the flow creates a shear stress greater than the critical shear stress of the bed material, sediment movement on bed occurs.
Incoming upstream sediment supplies the scour hole and cause fluctuations on the scour depth [3]. This type of scour is named as live-bed scour and corresponds to the case of $V>V_{c}$, in which $\mathrm{V}$ is the mean approach flow velocity and $V_{c}$ is the critical velocity for the sediment entrainment. If the flow cannot create a greater shear stress than the critical shear stress of the bed material, no sediment movement occurs on bed and the scour hole is not supplied with the sediment coming from the upstream. This type of scour is named as clear-water scour and it occurs when $V<V_{c}$.

In the steady flow case, the scour depth eventually reaches an equilibrium in both clear water and live bed scour conditions [3-7]. Live-bed equilibrium takes place when the amount of sediment supplied into the scour hole and that removed from the scour hole is equal to each other [3,5]. In other words, the live-bed equilibrium occurs when fluctuations in scour depth become stable. In clear-water scour and unsteady flow conditions, a state of equilibrium is assumed to be reached since the scour depth increases during the rising limb and its change during the falling limb is negligible $[8,9]$. Present experiments also revealed that the scour depth never reached a state of equilibrium in live-bed scour case during a flood hydrograph. 
Kothyari et al. [2] obtained similar results in their live-bed experiments under unsteady flow conditions. In this study, during the rising limb, the flow rate was the dominant element and scour depth increased, but during the falling limb, the transported sediment preserved its momentum longer and the scour depth began to decrease. Hence, in the case of flood hydrographs, it does not seem to be meaningful to use the equilibrium scour depth concept for the live-bed scour conditions.

\section{Experimental setup}

Experiments were carried out in a flume $18.6 \mathrm{~m}$ long, $0.8 \mathrm{~m}$ wide and $0.75 \mathrm{~m}$ deep constructed in the Hydraulic Laboratory of Civil Engineering Department of Dokuz Eylul University, within the scope of the project TÜBITAK 106M274. The channel bottom slope was equal to 0.006 . Three different circular piers were used during the experiments with $4 \mathrm{~cm}$ (D4), $8 \mathrm{~cm}$ (D8) and $11 \mathrm{~cm}$ (D11) diameters, placed at 12th meter of the flume. The first 8 meters and the last 5 meters of the flume bottom were composed of $20 \mathrm{~cm}$ thick gas concrete blocks. After the 3rd meter, the flume was covered with non-ripple forming sediment having $1.63 \mathrm{~mm}$ median diameter $\left(d_{50}\right)$ and 1.303 geometric standard deviation $(\sigma)$ to form a bed of $25 \mathrm{~cm}$. A schematic view of the flume is given in Fig. 1.

Water flows to the flume by means of a pump with $100 \mathrm{~L} / \mathrm{s}$ discharge capacity, connected to the speed control unit. The speed control unit regulates the pump's revolution speed to desired value within desired time with the aid of the software called DriveLink-C. Water returns to a reservoir of $27 \mathrm{~m}^{3}$ volume located below the downstream of the flume and pumped again to the flume simultaneously. Time dependent discharge was measured by an electromagnetic flow meter (OPTIFLUX 1000 manufactured by Krohne) mounted on the pipe before the inlet of the channel.

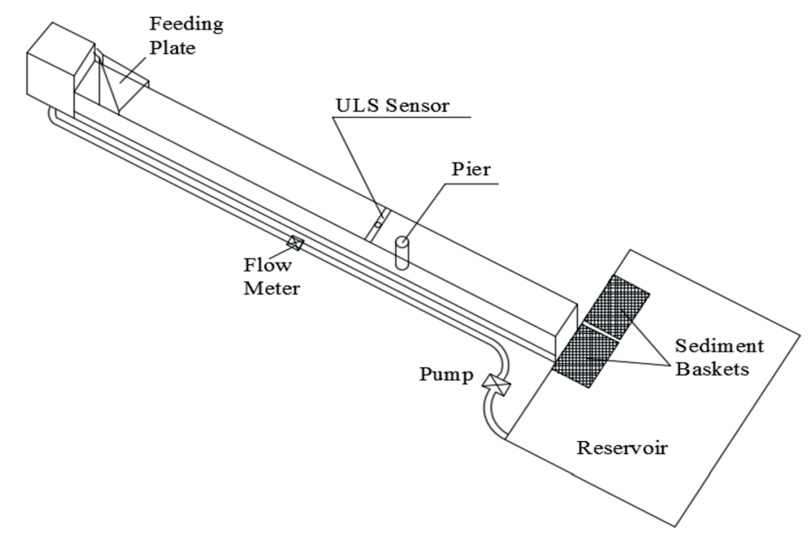

Fig. 1 Schematic view of the flume [10]

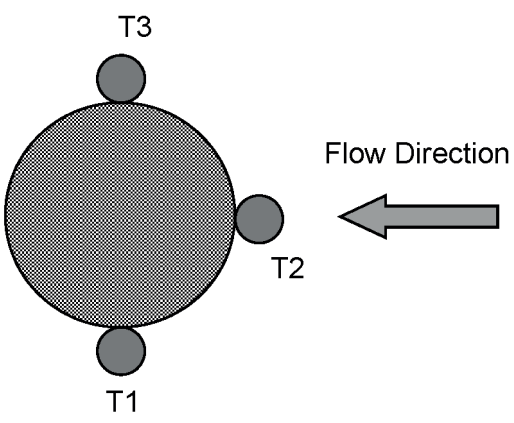

Fig. 2 Placement of the UVP transducers

Scour depth around the bridge pier was measured by Ultrasonic Velocity Profiler (UVP) device. As also stated in Guney et al. [11], it's possible to determine the bed morphology by using the UVP device which is normally designed for velocity measurement. The scour depth was determined from the echo amplitude values by placing UVP transducers vertically. Three transducers were used in this study namely, one at the upstream of the pier (T2) and two at the flanks of the pier (T1 and T3), as shown in Fig. 2.

The flow depth was measured by UltraLab ULS (Ultrasonic Level Sensor) manufactured by General Acoustics. The ULS sensor, used to measure the water surface with \pm 1 $\mathrm{mm}$ precision, was located at the 11th meter of the flume. The approach flow depth was measured at one meter from the pier, accordingly to the criterion $(B-b) / 2$, suggested by Oliveto and Hager [12], where $B$ and $b$ are the flume and pier width, respectively. The delay between the readings of the flow meter and those of the ULS, resulted from unsteady flow conditions, was corrected by adjusting the discharge and flow depth curves.

The sediment was fed into the flume manually, by means of the sediment feeding plate designed to provide uniform feeding and collected by the baskets located at the end of the flume. Each basket was replaced with another at intervals of $1 \mathrm{~min}$. In order to determine the amount of sediment to feed, a two-phased approach was adopted. First, the experiments were conducted for 7 of the hydrographs without sediment feeding, and the sediment load was collected minute by minute, dried and weighed. A regression analysis was performed to obtain a simple relationship between the discharge and the sediment load (sediment graph). Then, the experiments were carried out by feeding with these predetermined amounts.

\section{Experimental method}

16 different triangular hydrographs were generated with different characteristics, as indicated in Table 1. The name of the hydrograph $\left(H_{i j-k}\right)$ was defined so that the subscripts 
Table 1 Hydrograph characteristics

\begin{tabular}{lcccc}
\hline Hydrograph & $\begin{array}{c}\text { Base Flow } \\
(\mathrm{L} / \mathrm{s})\end{array}$ & $\begin{array}{c}\text { Peak } \\
\text { Discharge (L/s) }\end{array}$ & $\begin{array}{c}\text { Flood Duration (min) } \\
\text { Hiding }\end{array}$ & Falling \\
\hline Hid33-20 & 1.5 & 20 & 3 & 3 \\
Hid33-31 & 1.5 & 31 & 3 & 3 \\
Hid36-31 & 1.5 & 31 & 3 & 6 \\
Hid39-31 & 1.5 & 31 & 3 & 9 \\
Hid33-38 & 1.5 & 38 & 3 & 3 \\
Hid55-23 & 1.5 & 23 & 5 & 5 \\
Hid55-28 & 1.5 & 28 & 5 & 5 \\
Hid55-31 & 1.5 & 31 & 5 & 5 \\
Hid55-33 & 1.5 & 33 & 5 & 5 \\
Hid55-38 & 1.5 & 38 & 5 & 5 \\
Hid55-44 & 1.5 & 44 & 5 & 5 \\
Hid1010-28 & 1.5 & 28 & 10 & 10 \\
Hid1010-33 & 1.5 & 33 & 10 & 10 \\
Hid1010-44 & 1.5 & 44 & 10 & 10 \\
Hid1515-44 & 1.5 & 44 & 15 & 15 \\
Hid2020-44 & 1.5 & 44 & 20 & 20 \\
\hline
\end{tabular}

$i$ and $j$ denote rising and falling durations in minutes respectively, and the following subscripts $\mathrm{k}$ indicates the peak discharge of the hydrograph $(\mathrm{L} / \mathrm{s})$. A small base flow of $1.5 \mathrm{~L} / \mathrm{s}$ was selected to prevent scouring before the flood.

Before starting the experiments, the following preparations were realized:

1. Before leveling the sediment, the base flow was conveyed to the flume to get totally saturated sediment. Keeping the sediment in the same conditions before each experiment was necessary to be able to make a sound comparison.

2. After 20 minutes of water drainage, the whole sediment in the flume was leveled carefully by means of a scrapper plate moving on the rails over the flume walls.

3. The circular pier was mounted at the 12th meter of the flume at the centerline. ULS sensor was placed at the 11th meter of the flume.

During the experiments, the following steps were proceeded:

1. The desired hydrograph was generated by running the related software and the chronometer was started simultaneously at time 00:00 (minute : second).

2. At time 00:30, ULS software commenced to measure the bed level since the measured bed level was necessary to determine the flow depth.

3. Approximately at time 04:00, water entered the flume. Metal plates were used to prevent the scour caused by this initial flow. Any deformation around the pier was repaired by means of a trowel, if exists.

4. Approximately, at time 07:00, water reached the end of the flume and steady state conditions occurred. No scouring was observed during the base flow. A camera started to record the events around the pier during the experiment.

5. At time 10:00, the base flow ended and UVP software activated. UVP transducers started to measure the bed elevations around the pier.

6. The sediment was supplied into the flow according to the prescribed sediment graph. The transported sediment was collected by means of the baskets at the downstream end of the flume, minute by minute.

Once the experiment was completed, the following tasks were performed:

1. Photographs of the flume and the scour hole were taken.

2. The scour hole was profiled by means of a laser meter through the centerline of the flume.

3. The sediment collected from each basket was spread over sheets on the floor separately. The day after, the dried sediment was weighed and made ready to re-use for feeding in the succeeding experiment.

\section{Experimental observations and findings}

\subsection{Experimental observations}

During the base flow, no scouring was observed as it was intended. Initially, wake vortices started the scour process at the flanks of the pier and the scour depth at flanks were higher than that in front of the pier. With the development of the horseshoe vortices, the scour depth in front of the pier became greater and the maximum scour depth occurred at this point. Only 2D dune formations were observed.

During the rising limb, the development of the horseshoe vortices enhanced the size of the scour hole rapidly and the scour hole took the shape of a frustum. After the flow velocity reached its critical value, the bed material began to supply into the scour hole. Since the flow velocity increased continuously and the flow rate was higher than the sediment transport rate, the scour depth increased continuously with causing relatively low fluctuations in the scour depth until the peak discharge. The bed material removed from the scour hole was drifted to downstream, approximately 3-4 pier diameters away from pier, by the wake vortices.

As the falling limb started, the fluctuations in the scour depth became quite evident, especially under the hydrographs inducing high velocities. With the decreasing flow velocity, the transported sediment preserved its momentum longer and the sediment transport rate became the 
dominant element in scour depth. Sediment clusters continued to supply into the scour hole and each time, lesser amount of sediment removed from the scour hole because of the decreasing flow velocity. As the consequence of this process, the scour depth began to decrease. Thus, a final scour depth lower than the maximum scour depth occurred. This behavior of the scour mechanism was consistent with the results of Kothyari et al. [2] and it's also mentioned in Hong et al. [13]. The records obtained from of the transducer T2, for each pier under the hydrograph Hid2020-44, are given in Fig. 3, as an illustrative example.

\subsection{Effect of the duration of rising and falling limbs}

Hydrographs with the same peak discharge but different durations were classified separately in order to analyze the effect of the hydrograph duration. The asymmetric hydrographs were also examined in their own. The scour depth values obtained from the transducer T2 mounted on the pier D4, in the case of the hydrographs with the peak flow rate of $44 \mathrm{~L} / \mathrm{s}$, are given in Fig. 4, as an illustrative example.

As the duration of rising limb increased, the sediment was exposed to high velocities for a longer time. Consequently, it was observed that the maximum scour depth at the end of the rising limb increased with the increase in the duration of the rising limb. Due to the longer exposition to high

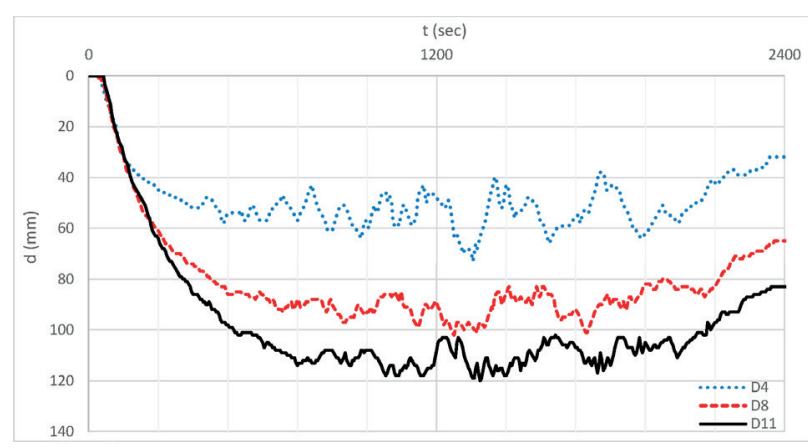

Fig. 3 Time dependent scour depths obtained from the transducer T2 in the case of Hid2020-44

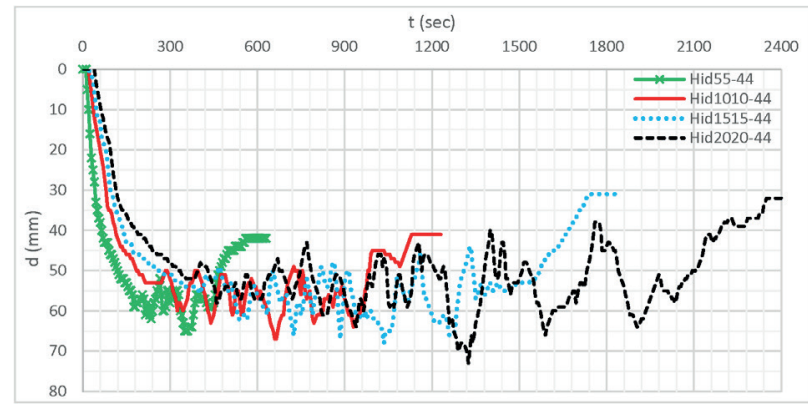

Fig. 4 Effect of the duration of the rising and falling limbs for the pier D4/transducer T2 velocities, the floods with longer duration increased the magnitude of the fluctuations on the scour depth. The flow rate was the dominant element of the scour during the rising limb. During the falling limb, the sediment transport rate became dominant element of the scour with decreasing discharge. As the duration of the falling limb became longer, the amount of the sediment supplied into the scour hole increased, so a lower final scour depth was observed. The difference between the maximum and final scour depths increased with the increase in the duration of the falling limb.

\subsection{Effect of the peak velocity}

The hydrographs with the same durations but different peak discharges were classified separately in order to analyze the effect of the peak flow velocity. It was observed that scouring was developed more rapidly with higher peak flow velocities, and higher velocities caused greater maximum scour depths, as expected. Higher velocities increased also the sediment transport rate causing two related consequences: First, the magnitude of the scour depth fluctuations were increased. Second, the final scour depths significantly decreased and resulted in larger differences with maximum scour depths, especially at piers with relatively small diameters. The scour depth values obtained from the transducer T2 mounted on the pier D4, in the case of the hydrographs with 10 minutes duration, are given in Fig. 5, as an illustrative example. As seen from this figure, Hid5544 possessing the greatest peak velocity caused the greatest scour depth but it also provided the lowest final scour depth.

\subsection{Effect of the pier diameter}

As it is known, and also observed in this study, the increase in pier diameter causes an increase in the scour depth and in the size of the scour hole. Since the amount of transported sediment was the same for a given hydrograph, the size of the scour hole determined how much the transported sediment affected the scour depth.

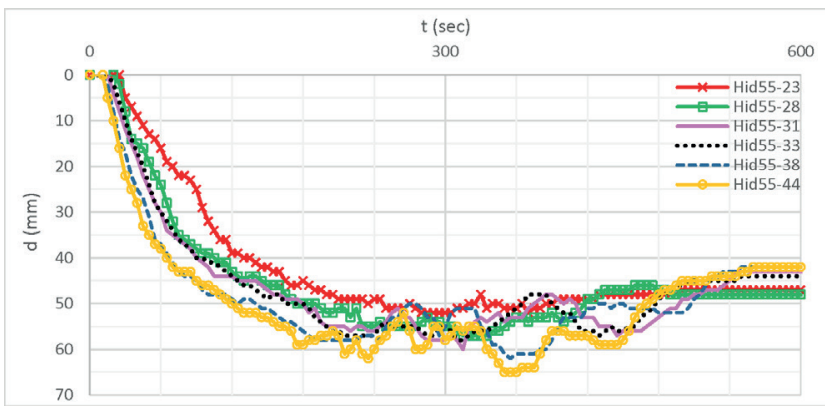

Fig. 5 Effect of the peak flow velocity for the pier D4/transducer T2 


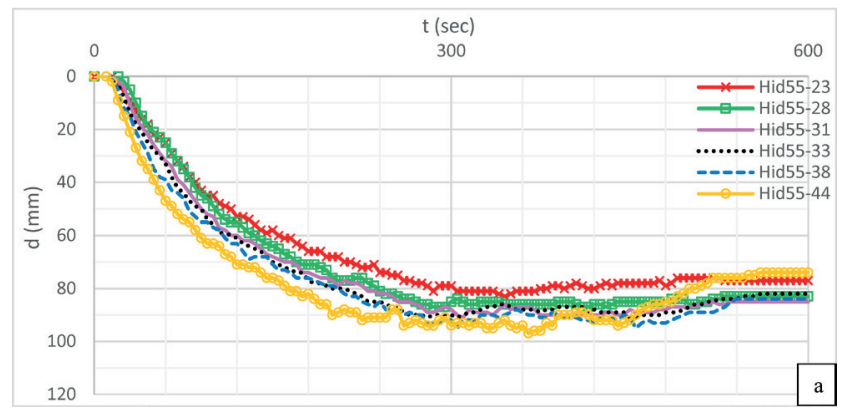

(a)

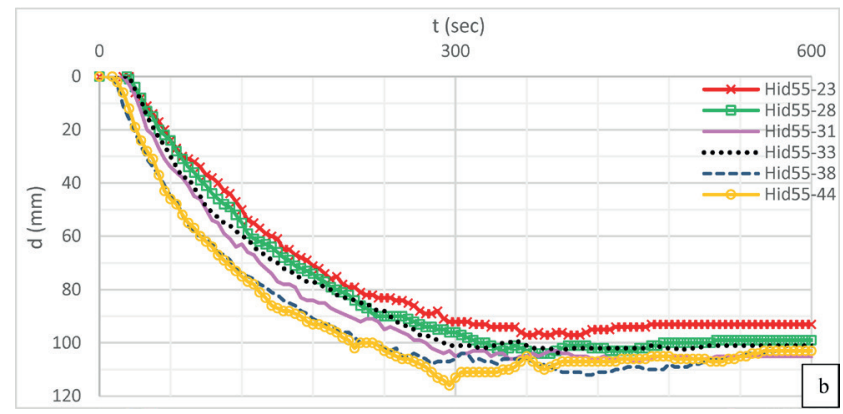

(b)

Fig. 6 a) Effect of the pier diameter for the piers D8 and b) D11 respectively, at the transducer $\mathrm{T} 2$

Naturally, the scour holes with smaller sizes were affected more from the same amount of the transported sediment. The scour depth values obtained for the pier D8 and D11, in the case of the hydrographs with 10 minutes duration, are given in Figs. 6(a) and 6(b) respectively, in order to determine the pier size effect. In Fig. 5, the scour depth curves intersected with each other more frequently because of the high fluctuations in the scour depth. These intersections decreased incrementally in Figs. 6(a) and 6(b), because of the increased size of the scour hole. Although Hid55-38 and Hid55-44 have the lowest final scour depths on Fig. 5, this is not the case in Figs. 6(a) and 6(b).

\section{Prediction of temporal scour depth}

Various regression analyses were performed by using huge amount of data consisting of 16 different hydrographs, 3 different pier diameters and timestep of 5 seconds, in order to derive an equation to predict the temporal livebed scour depth. The flow intensity $(V / V)$, the dimensionless flow depth $(y / b)$ and the dimensionless time $(T)$ were taken as effective parameters. Richardson and Davis [14] stated that "Bed material in the sand-size range has little effect on local scour depth". Ettema [15] and Melville [6] also stated that scour depth is not influenced from the sediment grain size when $b / d_{50}>25$. These values are approximately 24, 48 and 66 in this study, for the piers D4, D8 and D11 respectively. During the regression analysis, the effect of this parameter was found to be negligible. Since the maximum scour depth was observed nearly at the peak time, Eq. (1) was derived within the range of $0 \leq t \leq t_{p}$.

$$
\frac{d(t)}{b}=1.43\left(\frac{V}{V_{c}}-I_{v c}\right)^{0.37}\left(\frac{y}{b}\right)^{0.36}\left(1-e^{-0.007 T}\right),
$$

where $d(t)$ is the time dependent scour depth; $y$ is the approach flow depth; $b$ is the pier width; $I_{v c}$ is the threshold value of the flow intensity that causes the incipient sediment entrainment around pier and it was found as 0.6 in the present experiments. This value was suggested as 0.5 by Breusers et al. [16] and Raudkivi [17], 0.4 by Melville and Chiew [18] and Chang et al. [8]. Dongguang et al. [19] stated that $I_{v c}$ can change between 0.4 and 0.6. $T$ is the dimensionless time parameter, obtained from Eq. (2) for each timestep of flood. The reason of stating the time parameter by an exponential function is as follows; when $t=0,\left(1-e^{-T}\right)=0$; with continuously increasing flow velocity during the rising limb of a flood, when time to peak discharge (tp) approaches to $\infty,\left(1-e^{-T}\right)=1$ [20].

$T=\frac{\sqrt{g\left(\rho / \rho_{f}-1\right) d_{50}}}{b} t$,

where $\rho$ and $\rho_{f}$ are the densities of the sediment and the water, respectively.

$V_{c}$ can be calculated from Eq. (3) [6].

$\frac{\boldsymbol{V}_{\boldsymbol{c}}}{\boldsymbol{u}_{\boldsymbol{c}}}=5.75 \log \left(5.53 \frac{y}{d_{50}}\right)$

An approach to calculate the critical shear velocity, $u_{c}$, was given in Eqs. (4) and (5).

$u_{c}=0.0115+0.0125 d_{50}^{1.4} ; \quad 0.1 \mathrm{~mm}<d_{50}<1 \mathrm{~mm}$,

$u_{c}=0.0305 d_{50}^{0.5}-0.0065 d_{50}^{-1} ; \quad 1 \mathrm{~mm}<d_{50}<100 \mathrm{~mm}$,

where $u_{c}$ and $d_{50}$ are in $\mathrm{m} / \mathrm{s}$ and $\mathrm{mm}$, respectively.

Calculated and measured scour depths (denoted as $\mathrm{dc}$ and $\mathrm{dm}$, respectively) are given in Fig. 7, for each pier and hydrograph. The determination coefficients $\left(\mathrm{R}^{2}\right)$ and scatter indices (SI) are also indicated in Fig. 7. These values imply that the proposed empirical relation is statistically significant.

\section{Prediction of maximum scour depth}

Since the maximum scour depth is the primary requirement for design purposes, an equation involving the same effective parameters was investigated to determine the maximum live-bed scour depth under unsteady flow conditions. 

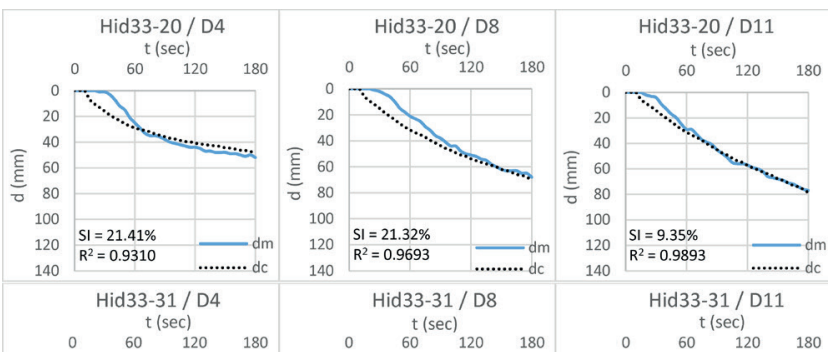

\begin{tabular}{ll}
100 & $\mathrm{SI}=9.35 \%$ \\
\hline $\mathrm{R}^{2}=0.9893$
\end{tabular}

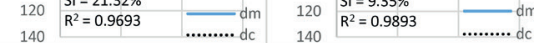
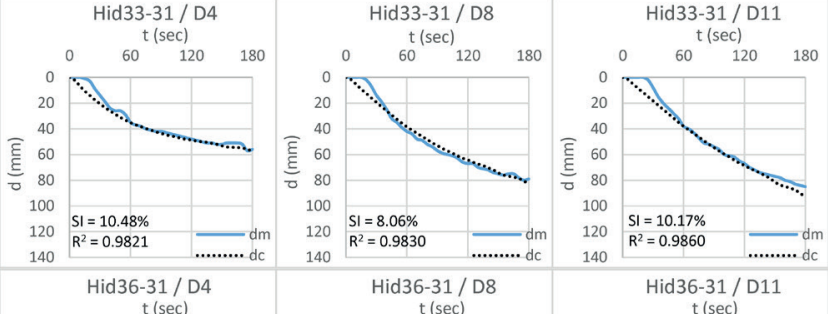

\begin{tabular}{l|l}
120 & $\mathrm{SI}=10.17 \%$ \\
$\mathrm{R}^{2}=0.9860$ & $\mathrm{dm}$
\end{tabular}
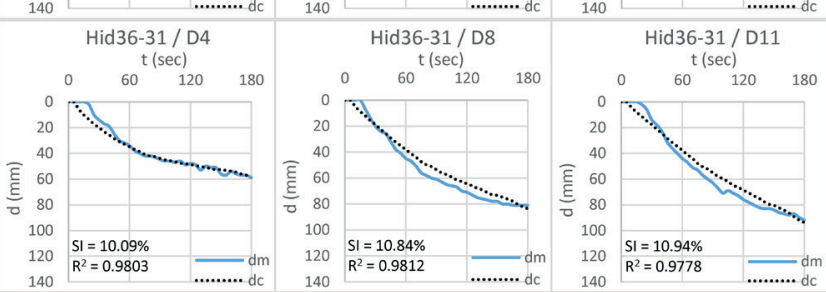

$120 \mathrm{SI}=10.94 \%$
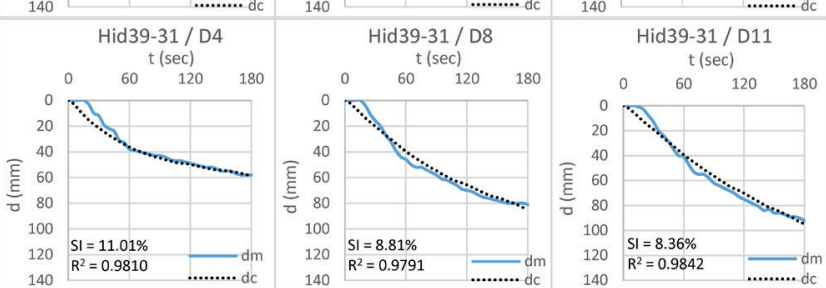

Hid33-38 / D4
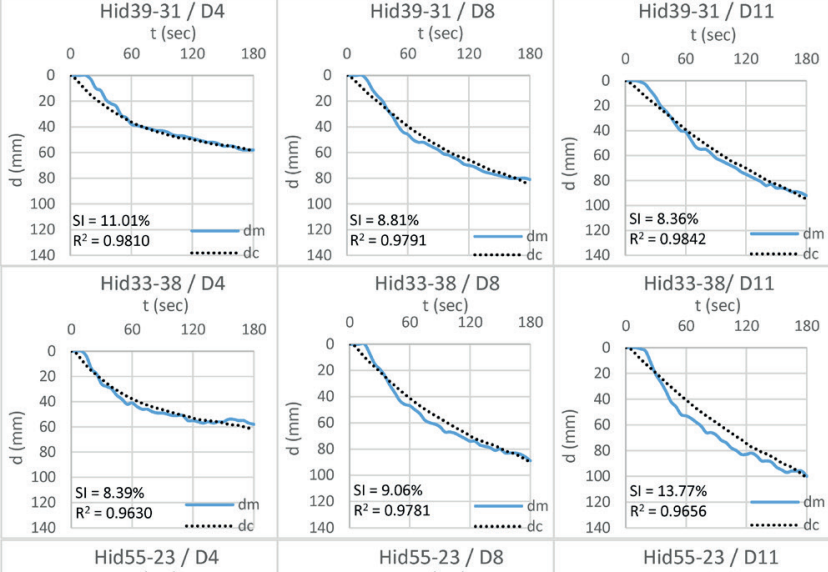

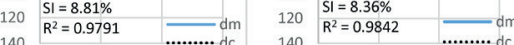
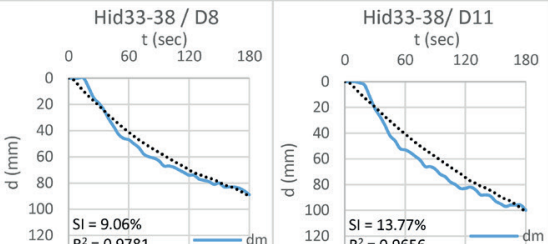

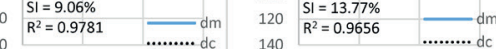

t $(\mathrm{sec})$

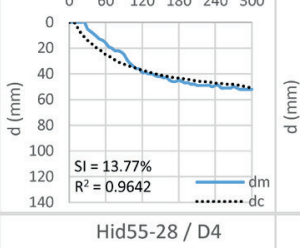

Hid55-23 / D8

Hid55-23 / D11

$\begin{array}{cccc}t(\mathrm{sec}) \\ 0 \quad 60 & 120 & 180 & 240 \quad 300\end{array}$

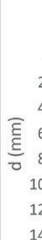

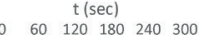
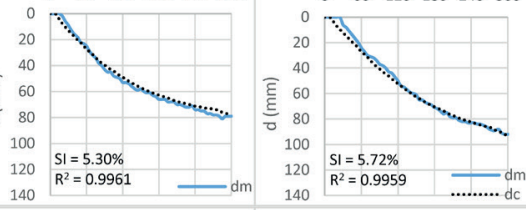

$\mathrm{SI}=5.72 \%$

$=0.9959 \quad \ldots \ldots . . m$

Hid55-28 / D11

$\mathrm{t}(\mathrm{sec})$
$60 \quad 120180 \quad 240 \quad 300$
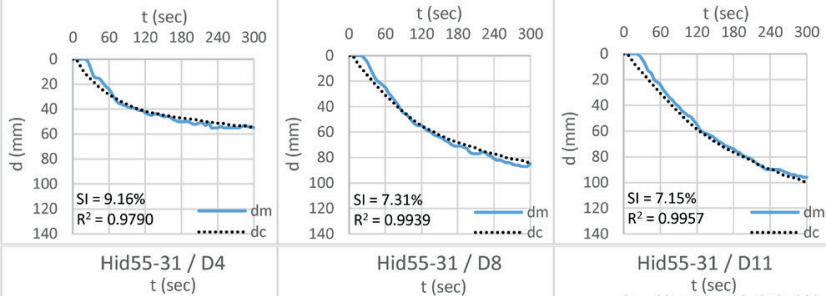

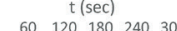

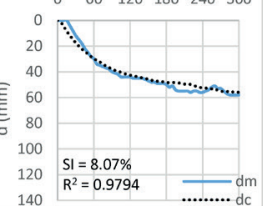

$\mathrm{t}(\mathrm{sec})$
$0 \quad 60 \quad 120180240300$

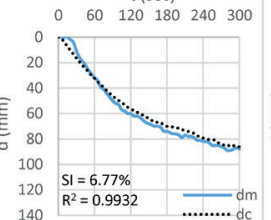

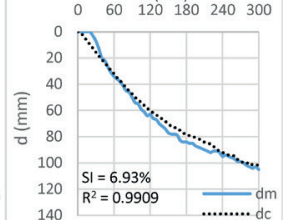
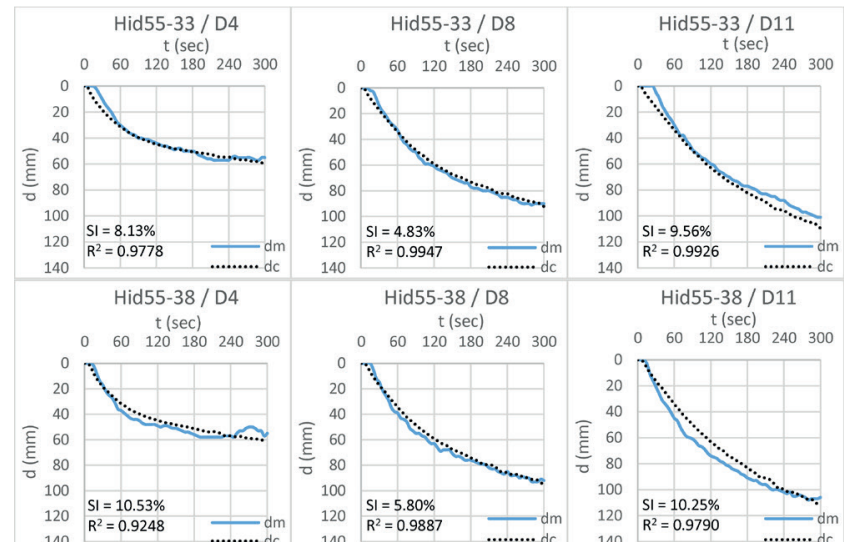

Hid55-38 / D

Hid55-38 / D11

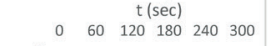

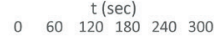
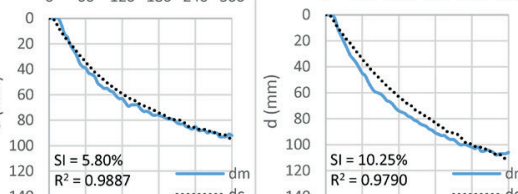

Hid55-44 / D8

$\mathrm{t}(\mathrm{sec})$

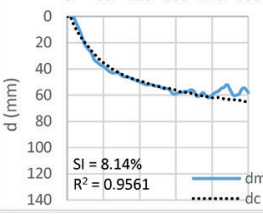

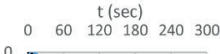

$\begin{array}{ll}60 & t(\mathrm{sec}) \\ 120 & 180-240-300\end{array}$
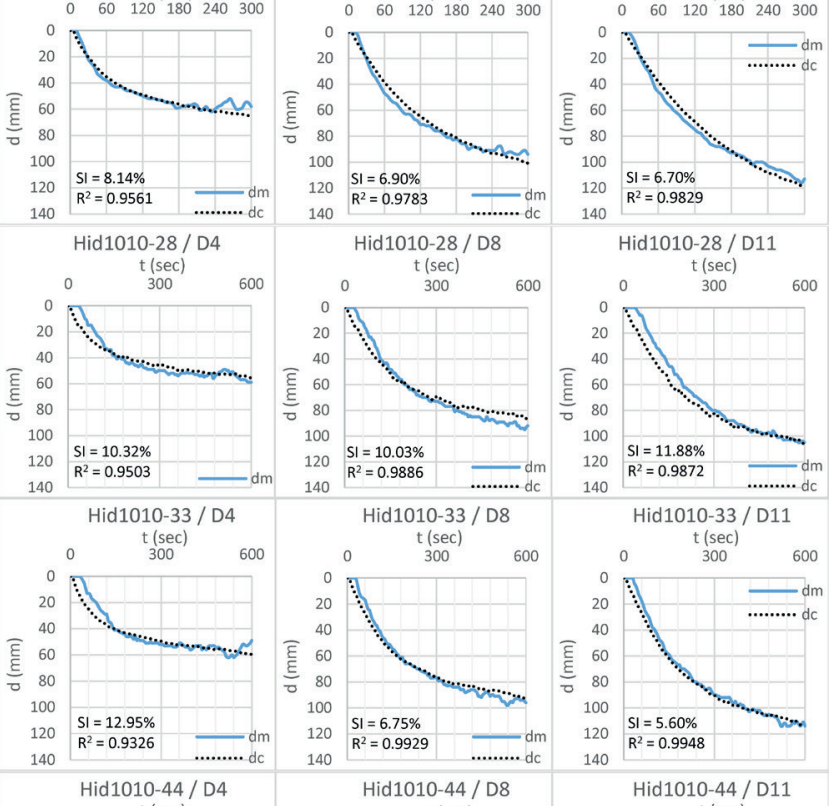

Hid1010-33/ D11
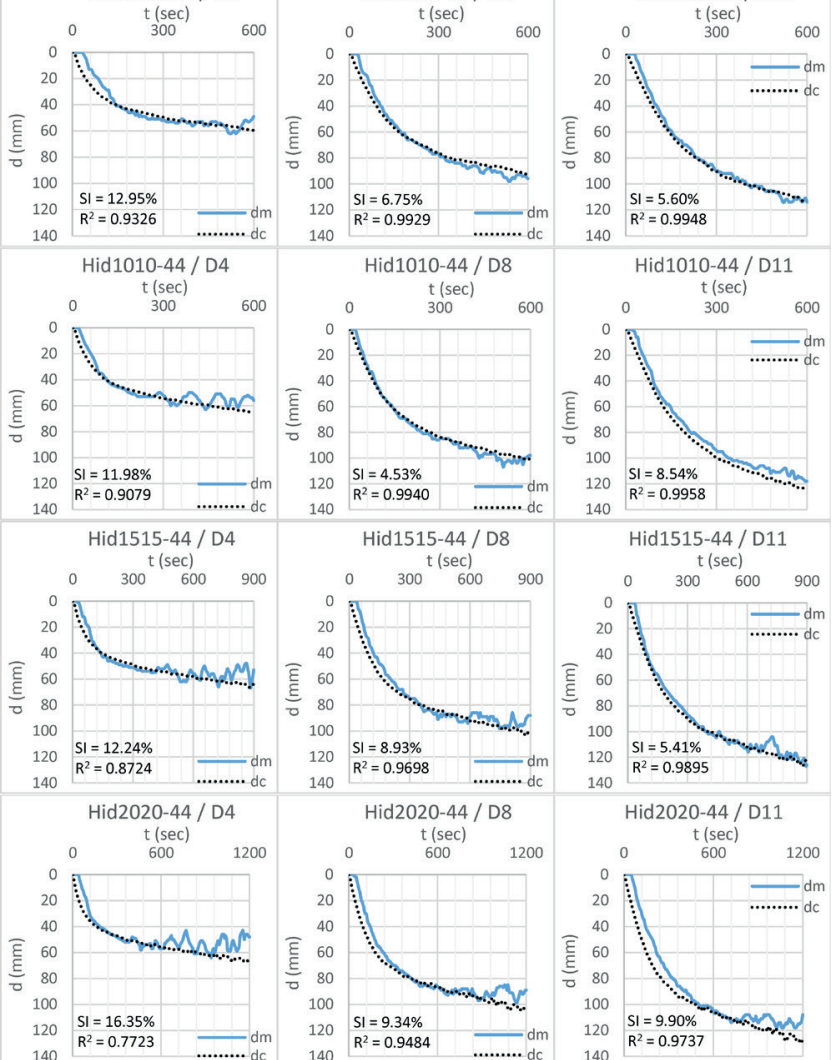

Fig. 7 Calculated and measured scour depths 
The so obtained equation is:

$$
\frac{d_{m}}{b}=0.86\left(\frac{V}{V_{c}}\right)_{p}^{0.11}\left(\frac{y}{b}\right)_{p}^{0.38} T_{p}^{0.045},
$$

where the subscript $p$ indicates peak value of the given parameters. The dimensionless time to peak, $T_{p}$, can be obtained from Eq. (2) by taken $t_{p}$ for time $t$. Numerical values obtained from Eq. (6) were compared with the experimental findings and the results are given in Fig. 8, with scatter indices (SI). Determination coefficients $\left(\mathrm{R}^{2}\right)$ were obtained as $0.92,0.81$ and 0.87 for the piers D4, D8 and D11, respectively.

\section{Conclusions}

The following conclusions were obtained from the study:

1. During the rising limb of the flood hydrograph, the flow rate was dominant element of the scour. Scour depth began to increase quickly and sediment movement affected scour depth and fluctuation heights insignificantly.

2. During the falling limb of the flood hydrograph, the sediment transport rate became dominant element of the scour. The magnitudes of scour depth fluctuations became greater and the sediment supplied into the scour hole caused decrease in scour depth.

3. Maximum scour depths increased with increase in the duration of the rising limb and longer duration of floods induced higher fluctuations in scour depth. As the duration of falling limb became longer, the amount of sediment supplied into the scour hole increased, so a lower final scour depth was observed.

4. Scouring developed more rapidly with high velocities and higher velocities caused greater maximum scour depths. Magnitudes of scour depth fluctuations increased with increase in the flow velocity. Greater velocities caused greater rate of sediment transport, so difference between maximum scour depth and final scour depth increased with increase in the flow velocity. Thus, higher peak discharges provided lower final scour depths in the case of piers with relatively small diameters.

5. Heights of fluctuations and decrement of scour depth during the falling limb were also affected from the pier widths. Scour holes with relatively small sizes were more affected from the sediment transport.

6. Eq. (1) can be used to predict temporal scour depth in the range of $0 \leq t \leq t_{p}$. Statistically significant determination coefficients and scatter indices were obtained.

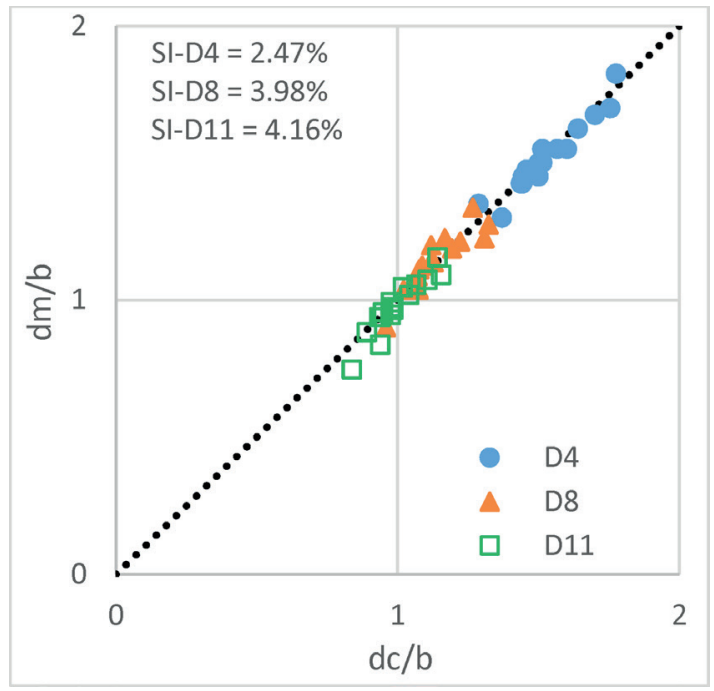

Fig. 8 Calculated and measured scour depths

7. Eq. (5) is proposed to predict the maximum live-bed scour depth. Statistically significant determination coefficients and scatter indices were obtained.

\section{Notation}

The following symbols are used in this paper:

$B=$ flume width;

$b=$ pier width;

$d=$ scour depth

$d c=$ calculated scour depth;

$d_{m}=$ maximum scour depth;

$d m=$ measured scour depth;

$d_{50}=$ median grain diameter;

$g=$ gravitational acceleration;

$I_{v c}=$ flow intensity that causes incipient sediment entrainment around pier;

$T=$ dimensionless time;

$T_{p}=$ dimensionless time to peak discharge;

$t=$ time;

$t_{p}=$ time to peak discharge;

$u_{c}=$ critical shear velocity;

$V=$ mean approach flow velocity;

$V_{c}=$ critical mean velocity for sediment entrainment on bed;

$y=$ flow depth;

$\rho=$ density of the sediment;

$\rho_{f}=$ density of the water; and

$\sigma=$ geometric standard deviation of bed material. 


\section{References}

[1] Wardhana, K., Hadipriono, F. C. "Analysis of Recent Bridge Failures in the United States", Journal of Performance of Constructed Facilities, 17(3), pp. 144-150, 2003. https://doi.org/10.1061/(ASCE)0887-3828(2003)17:3(144)

[2] Kothyari, U. C., Raju, K. G. R., Garde, R. J. "Live-bed scour around cylindrical bridge piers", Journal of Hydraulic Research, 30(5), pp. 701-715, 1992.

https://doi.org/10.1080/00221689209498889

[3] Chiew, Y. M. "Local Scour at Bridge Piers", PhD thesis, The University of Auckland, 1984. [online] Available at: https://researchspace. auckland.ac.nz/handle/2292/2520 [Accessed: 15 June 2017]

[4] Laursen, E. M., Toch, A. "Scour Around Bridge Piers and Abutments", Bulletin No.4, Iowa Institute of Hydraulic Research, Ames, IA, USA, 1956. [online] Available at: https://core.ac.uk/ download/pdf/76635144.pdf [Accessed: 22 October 2018]

[5] Jain, S. C., Fischer, E. E. "Scour Around Circular Bridge Piers at High Froude Numbers", US Department of Transportation Federal Highway Administration, Washington, DC, USA, Rep. DOT-FH-11-9276, 1979. [online] Available at: https://ntrl.ntis.gov/ NTRL/dashboard/searchResults/titleDetail/PB80139322.xhtm1 [Accessed: 02 October 2018]

[6] Melville, B. W. "Pier and Abutment Scour: Integrated Approach", Journal of Hydraulic Engineering, 123(2), pp. 125-136, 1997. https://doi.org/10.1061/(ASCE)0733-9429(1997)123:2(125)

[7] Sheppard, D. M., Miller Jr., W. "Live-Bed Local Pier Scour Experiments", Journal of Hydraulic Engineering, 132(7), pp. 635$642,2006$.

https://doi.org/10.1061/(ASCE)0733-9429(2006)132:7(635)

[8] Chang, W. Y., Lai, J. S., Yen, C. L. "Evolution of Scour Depth at Circular Bridge Piers", Journal of Hydraulic Engineering, 130(9), pp. 905-913, 2004. https://doi.org/10.1061/(ASCE)0733-9429(2004)130:9(905)

[9] Hager, W. H., Unger, J. "Bridge Pier Scour under Flood Waves", Journal of Hydraulic Engineering, 136(10), pp. 842-847, 2010. https://doi.org/10.1061/(ASCE)HY.1943-7900.0000281

[10] Gumgum, F. "Experimental and Numerical Investigation of the Local Scour around Bridge Piers in the Case of Sediment Feeding", $\mathrm{PhD}$ thesis, Dokuz Eylul University, 2019.
[11] Guney, M. S., Bombar, G., Aksoy, A. O., Dogan, M. "Use of UVP to investigate the evolution of bed configuration", KSCE Journal of Civil Engineering, 17(5), pp. 1188-1197, 2013. https://doi.org/10.1007/s12205-013-0131-5

[12] Oliveto, G., Hager, W. H. "Temporal Evolution of Clear-Water Pier and Abutment Scour", Journal of Hydraulic Engineering, 128(9), pp. 811-820, 2002. https://doi.org/10.1061/(ASCE)0733-9429(2002)128:9(811)

[13] Hong, J. H., Chiew, Y. M., Yeh, P. H., Chan, H. C. "Evolution of Local Pier-Scour Depth with Dune Migration in Subcritical Flow Conditions", Journal of Hydraulic Engineering, 143(4), Article number: 04016098, 2016. https://doi.org/10.1061/(ASCE)HY.1943-7900.0001261

[14] Richardson, E. V., Davis, S. R. "Evaluating scour at bridges", Federal Highway Administration, Washington, USA, 2001.

[15] Ettema, R. "Scour at bridge piers", PhD thesis, The University of Auckland, 1980.

[16] Breusers, H. N. C., Nicollet, G., Shen, H. W. "Local Scour Around Cylindrical Piers", Journal of Hydraulic Research, 15(3), pp. 211252, 1977. https://doi.org/10.1080/00221687709499645

[17] Raudkivi, A. J. "Functional Trends of Scour at Bridge Piers", Journal of Hydraulic Engineering, 112(1), pp. 1-13, 1986. https://doi.org/10.1061/(ASCE)0733-9429(1986)112:1(1)

[18] Melville, B. W., Chiew, Y. M. "Time Scale for Local Scour at Bridge Piers", Journal of Hydraulic Engineering, 125(1), pp. 59-65, 1999. https://doi.org/10.1061/(ASCE)0733-9429(1999)125:1(59)

[19] Dongguang, G., Pasada, L., Nordin, C. F. "Pier Scour Equations Used in the People's Republic of China: Review and Summary", US Office of Technology Applications Federal Highway Administration, Washington, DC, USA, Rep. FHWA-SA-93-076, 1993. [online] Available at: https://rosap.ntl.bts.gov/view/dot/855 [Accessed: 12 Octorber 2018]

[20] Dogan, M., Arisoy, Y. "Time development of local scour depth below pipelines exposed to waves", Coastal Engineering Proceedings, 1(34), Posters 9, 2014.

https://doi.org/10.9753/icce.v34.posters.9 